\title{
An epidemiological and therapeutic study of Sarcoptes scabiei parasite in cows of Anbar province, Iraq
}

\author{
S.Sh. Shahatha ${ }^{\circledR}$, I.M. Ayyed ${ }^{\circledR}$ and M.O. Mousa \\ Center of Desert Studies, University of Anbar, Anbar, Iraq
}

\begin{tabular}{l} 
Article information \\
\hline Article history: \\
Received January 24, 2021 \\
Accepted May 04, 2021 \\
Available online November 20, 2021 \\
\hline Keywords: \\
Abamectin \\
Nitol plant \\
Prevalence \\
Scabies mite \\
\\
\hline Correspondence: \\
S.Sh. Shahatha \\
suad.alfahdawi@uoanbar.edu.iq
\end{tabular}

\begin{abstract}
This study was conducted to determine the prevalence of Sarcoptes scabiei infection in cows in Anbar province, Iraq. The parasite was diagnosed in the laboratory via examining skin scrapings taken from the suspected cows. The results indicated that the infection rate in cows with S. scabiei reached $37.5 \%$, the animals of 3 months - <3 years old have the highest rate of infection. The results of the study showed that head lesions were more present and clearer than others. Furthermore, the highest rate of infection was recorded in the winter season and the lowest in the summer season. It has been proven that the concentration of (510) $\mathrm{mg} / \mathrm{ml}$ of the aquatic extract of Hammada articulate had a great effect on the parasite, however, the concentration $10 \mathrm{mg} / \mathrm{ml}$ leads to the complete disappearance of all parasites and the cure of the infected cows on the 14th day of treatment, which is equal to the drug Abamectin in its effect on the parasites. The current study concluded that cows in the study areas were infected with scabies mites at a high rate, and this calls for finding safe treatment methods by using medicinal herbs and plants because they contain many active compounds that affect the parasite and lead to its mortality, and they are safe strategic alternatives to harmful chemical drugs. This necessitates the establishment of an integrated control approach through treatment with effective plant extracts and to maintain the cleanliness of the animal environment.
\end{abstract}

DOI: $10.33899 /$ ijvs.2021.129420.1646, (CAuthors, 2022, College of Veterinary Medicine, University of Mosul.

This is an open access article under the CC BY 4.0 license (http://creativecommons.org/licenses/by/4.0/).

\section{Introduction}

Sarcoptes scabiei, or itch mite, is an obligate ectoparasite that infects the skin of a wide range of animals causing mange, it is an important disease that causes heavy economic losses due to its ability to negatively affect livestock production and can increase the mortality rate (1). This disease has a wide global spread, especially in developing countries, S. scabiei belongs to class Arthropoda and order of Acarina and the family of sarcoptidae (2). It affects many species of wild and domestic animals, including cows, sheep, goats, buffaloes, rabbits, dogs, cats, and they may also infect wild boars, bears, koalas and monkeys (3).

Approximately, more than 100 mammal species belonged to 27 families can be affected, these parasites burrow deep into the skin and form $1 \mathrm{~cm}$ long tunnels in where they feed and multiply, causing an inflammation, severe itching, excoriation, and hair loss, the parasite causes different clinical manifestations including wasting, weight loss, anemia, severe itching, dermatitis, local bleeding, ulcers, hair loss, low production of meat and milk, and might terminated with decimation of animals (4).

Several studies have been conducted to investigate the scabies parasite in many countries around the world. For example, in Ethiopia, an infection rate of $10.9 \%$ in examined cows was recorded (5). on the other hand, Haggag et al. (6) indicated a $48 \%$ infection rate among ows in Behera province, Egypt. As for Iraq, a study conducted in Duhok province, north Iraq, which recorded a rate of $57.7 \%$ (7). As well, Mustafa (8) mentioned an infection rate of $13.8 \%$ in Sulaymaniyah province, while Shahatha (9) found the incidence rate of $34.6 \%$ in Anbar province. 
Many medicinal plants and herbs have been used in the treatment of diseases, including parasitic diseases because they contain many effective compounds including alkaloids, fuocumarins, glycosides, resins, tannins, volatile oils, saponins, and others, the Nitol or Hammada articulate plant belongs to the Chenopodiaceae family, which is characterized as a small shrub, about 40-95 $\mathrm{cm}$ high, with deep roots and a strong dry base, prefers gravel and fossilized soil as well as clay soil, and blooms from early July to midOctober, it is characterized by containing many compounds effective including alkaloids, fuocumarins, glycosides, flavones, tannins, volatile oils, and saponins, it is used for the treatment of skin diseases, including scabies in animals, as well as for treating skin eczema in humans (10).

From the studies conducted to treat scabies, a study done by Aboelhadid et al. (11) appear the, in vitro and in vivo effect of Citrus limon essential oil against sarcoptic mange in rabbits. On the other hand, Li et al. (12) also studied the effect of lemongrass oil on S. scabiei parasites.

Scabies disease causes great economic losses and leads to a decrease in animal production and the death of large numbers of animals, it affects various types of animals in most countries of the world, including Iraq, so this study was conducted to determine the extent of the prevalence of scabies mites in cows in Anbar province and to find a safe and effective treatment for this disease using medicinal plants and herbs, the aqueous extract of the Nitol plant was used because it contains many effective compounds, which are considered a good strategic alternative to chemical drugs that harm human health, animals, and the environment.

This study provides a basis for exploring the therapeutic potential of these medicinal plants against parasitic diseases. However, extensive studies are needed to determine the effectiveness of the active compounds of other plants, which may lead to a significant addition of value in the pharmaceutical industry, and to provide a cost-effective method of treatment with minimal side effects.

\section{Materials and methods}

\section{Animals and study area}

A total of 416 suspected cows were examined from both sexes and at different ages ranged from 3 months to 15 years, animals are located in different areas in Anbar province including Sufism, Al-Jazeera, Saqlawiyah, Habbaniyah, Fallujah, and Hit.

The skin scrapings were examined in the laboratory to diagnose and watch the S. scabiei parasites. The study also included the effect of different concentrations of the aquatic extract of Hammada articulate, also known locally as a Nitol plant, and its comparison with the drug Abamectin on the parasites.

\section{Collection and examination of samples}

Skin scrapings were taken from different groups of cows present in livestock fields in Anbar province for one year, an average of thirty percent of cows per farm and 15 percent of every village visited were included in this study. After selecting the animals, each cow was attached and hair was trimmed from the lesion margins with scissors then the area was cleaned with a $10 \% \mathrm{KOH}$ solution (13). The lesions were scraped from the ends using a sterile scalpel until blood bled from the site and samples were collected monthly (about 40 samples) and placed in glass bottles and brought to the Parasitology Laboratory for examination according to the method used by Cloes (14), by adding $10 \mathrm{ml}$ of $10 \% \mathrm{KOH}$ solution and placed in a water bath of $80^{\circ} \mathrm{C}$ for 20 minutes to remove the tissue and fiber. Then the cooled samples were placed in the centrifuge at a speed of $1500 \mathrm{cycles} / \mathrm{min}$ for 5 minutes, a drop of the precipitate was examined microscopically at $40 \mathrm{x}, 100 \mathrm{x}$ for final diagnosis of the causative parasite.

\section{Infection level estimation}

The level of infection for each infected animal was estimated by counting the number of scabies mites in all its stages in 10 light fields under the magnification force of 40 $\mathrm{X}$, and then dividing the resulting number on the number 10 , and the standard is the number of mite / light field (15).

\section{Preparation of the aquatic extract of the Nitol plant}

The Nitol plant (Figure 1) was collected from the 70th kilometer west of Rutba, for the purpose of preparing the aqueous extract of the plant which was diagnosed in Herbarium - University of Anbar. The plants were cleaned and dried in an incubator set at $30-35^{\circ} \mathrm{C}$. The plant was extracted according to Kanojiya et al. method (16) by crushing 40 grams of the plant with $160 \mathrm{ml}$ of distilled water in a ratio of 4:1 using a blender. The mixture was placed inside a snow bath to ensure that the active compounds were not harmed by the high temperature. The substance was then mixed for 60 minutes using an electric magnetic motor (stirrer) and left the mixture for 24 hours at $4{ }^{\circ} \mathrm{C}$ for the purpose of soaking.

After that, the mixture was nominated using filtration papers to dispose of plant fiber parts, then the plant extract was dried using a lyophilizer. The powder was stored after the drying process in glass bottles at $-10^{\circ} \mathrm{C}$ until use. The standard concentration of the extract was prepared by taking 2 grams of raw extract and $20 \mathrm{ml}$ of distilled water. Based on the standard concentration $(100 \mathrm{mg} / \mathrm{ml})$, and then the required concentrations $5,7.5,10 \mathrm{mg} / \mathrm{ml}$ were prepared.

\section{Chemical detection of active compounds in plant (17) Detection of glycosides}

$1 \mathrm{~g}$ of a dry plant extract was mixed with $10 \mathrm{ml}$ distilled water, added a few drops of Fehlink reagent, the appearance of red indicates the presence of Glycosides. 


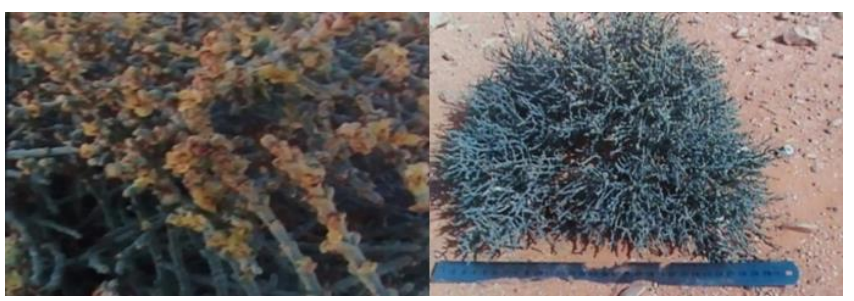

Figure 1: The Nitol plant Hammada articulate.

\section{Detection of fuocumarins}

Two equal amounts of a plant extract were mixed with $1 \%$ potassium hydroxide; the appearance of greenish-yellow indicates the presence of Fuocumarins.

\section{Detection of flavonoids}

A $10 \mathrm{ml}$ solution of $50 \%$ ethanol was added to $10 \mathrm{ml}$ of $50 \%$ potassium hydroxide and mixed in an equal amount, the presence of a yellow color indicated the existence of Flavonoids.

\section{Detection of terpenes}

A mixture of the following chemical materials was prepared: One gram of plant extract was dissolved in $2 \mathrm{ml}$ of chloroform, followed by a drop of anhydrous acetic acid and a drop of concentrated sulfuric acid, the presence of brown sediment indicated the existence of Terpenes.

\section{Detection of alkaloids}

10 grams of plant extract was boiled with $50 \mathrm{ml}$ of distilled water containing $4 \%$ hydrochloric acid (HCL). The solution was cooled and filtered. Following this, $0.5 \mathrm{ml}$ of leachate was tested in a watch glass with $0.5 \mathrm{ml}$ of Meyer reagent, the appearance of white deposits indicates the presence of Alkaloids.

\section{Detection of tannins}

A few drops of lead acetate solution $1 \%$ were added to 5 $\mathrm{ml}$ of the plant extract; the appearance of white gelatin deposits indicates the presence of tannins.

\section{Detection of phenols}

$1 \mathrm{ml}$ of dry plant extract was added to $1 \mathrm{ml}$ of a $1 \%$ ferric chloride solution, the appearance of green or blue color indicating the presence of phenols.

\section{Detection of the saponins}

$3 \mathrm{ml}$ of mercuric chloride solution $1 \%$ was added to $5 \mathrm{ml}$ of the plant extract, the appearance of the white deposit indicated the presence of saponins.

\section{Detection of volatile oils}

A few drops of plant extract were added to the filter paper to reduce saturation and exposure to ultraviolet radiation, the appearance of a grayish color indicates the presence of volatile oils.

\section{Treatment experiment}

The experiment was carried out on a herd of cows infected with the mange in Saqlawiya district of Fallujah, which is 50 heads. The herd was divided into 5 groups, Group 1 was considered a control group, and group 2 was treated with Abamectin drug $\left(\right.$ GENESIS $\left.^{\mathrm{TM}}\right)$ with a dose of $0.2 \mathrm{mg} / \mathrm{kg}$ of body weight (the recommended dose) by SC for one-time injection. Moreover, group 3 was treated with a concentration of $5 \mathrm{mg} / \mathrm{ml}$ of the aquatic extract of the Nitol plant by subcutaneous injection. Group 4 was treated with $7.5 \mathrm{mg} / \mathrm{ml}$ of the aquatic extract of the Nitol plant. The group 5 was treated with $10 \mathrm{mg} / \mathrm{ml}$ of the aquatic extract of the Nitol plant. A clinical examination was performed and an estimate of the level of infection for all animals was performed by collecting the levels of infection of the group animals and dividing them by the number of group infected animals on days $0,7,14$, and 21 after treatment with aquatic extract of the plant and the drug used.

\section{Statistical analysis}

The data collected on disease prevalence were analyzed statistically using different statistical techniques by Statically Analysis Software (SAS) application (proc) for Windows version 10 (18). The prevalence of mange was assessed using descriptive statistics. Chi-square was applied to confirm disease spread based on sex, seasons, and age; the results were compared using least significant difference (LSD), data on the presence of lesions were collected to estimate the percentage of their appearance on different body parts. For the therapeutic study, results and data generated from the trial were expressed as mean \pm standard error for continuing variants, using the one-way analysis of variance (ANOVA) table, at a probability level $\mathrm{P}<0.05$.

\section{Results}

This study is the first of its kind in a country where the Nitol plant is used to treat $S$. scabiei parasites. The results revealed a $37.5 \%$ infection rate of the $S$. scabiei parasite in Anbar province. The S. scabiei was characterized by its small size and flat spherical shape from both the ventral and dorsal sides. The legs were short and not prominent in both sexes. Females had three sensory spines in the front of the midline and six in the back, while in males the sensory spines are hairy (Figure 2). It was noted that the infection rate between males and females is close (Table 1). As for the relationship of infection with animal age, the highest infection rate was $56.1 \%$ in cows at ages 3 months- $<3$ years old and the lowest was $19.3 \%$ at ages $9-<12$ years, with significant differences (Table 2). 


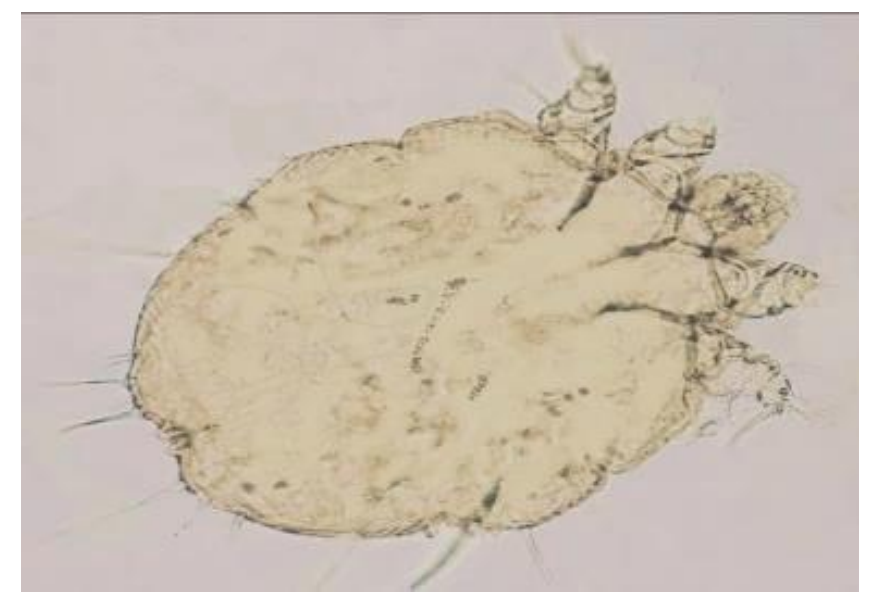

Figure 2: Sarcoptes scabiei parasite in the examined skin scrapings, $40 \mathrm{X}$.

Table 1: Percentage of infection with S. scabiei according to $\operatorname{sex}$

\begin{tabular}{lccc}
\hline sex & n examined & n infected & $\%$ \\
\hline Males & 202 & 74 & 36.6 \\
Females & 214 & 82 & 38.8 \\
\hline Total & 416 & 156 & 37.5 \\
\hline
\end{tabular}

Table 2: Percentage of infection with S. scabiei according to age

\begin{tabular}{lccc}
\hline Age (year) & n examined & n infected & $\%$ \\
\hline$<3$ & 89 & 50 & 56.1 \\
$3-<6$ & 80 & 35 & 43.7 \\
$6-<9$ & 81 & 32 & 39.5 \\
$9-<12$ & 88 & 17 & 19.3 \\
$12-<15$ & 78 & 22 & 28.2 \\
\hline Total & 416 & 156 & 37.5 \\
\hline
\end{tabular}

The disease was clinically characterized by thickening and waviness of the skin, , hair loss and severe itching in most cows. Scabies lesions were most commonly observed on the head, followed by the back and neck respectively of the affected cows (Figure 3).

The head lesions were more present and more pronounced than others, where the highest was recorded. The percentage was $33.3 \%$, followed by the back lesions $31.4 \%$, while the back legs lesions recorded the lowest rate of $1.2 \%$ with significant differences (Table 3 ).

The seasonal results showed that the highest prevalence of scabies mites was observed during the winter season, followed by autumn and then spring, while the lowest prevalence of the parasites was observed in the summer, with incidence rates reaching 59.6, 40, 33.6, and $16 \%$, respectively with statistically significant differences (Table 4).

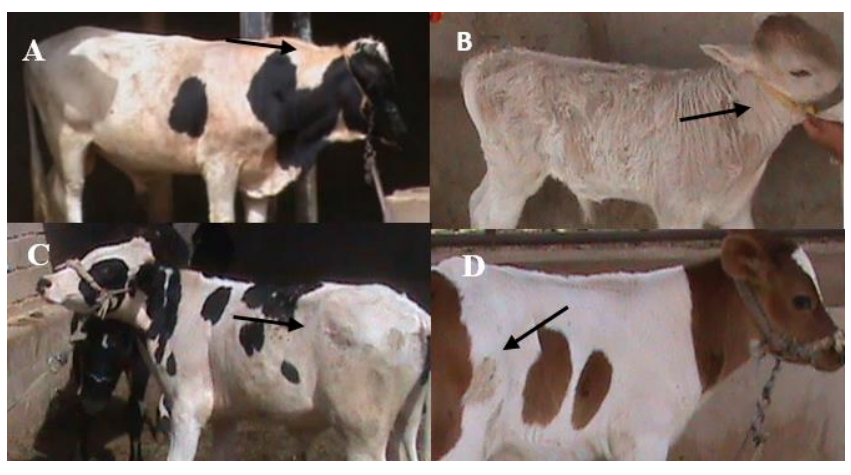

Figure 3: Mange at different regions of the body (A) at head, (B) at neck, (C) at back, (D) at back leg.

Table 3: Percentage of infection with lesions S. scabiei according to location on the body

\begin{tabular}{lcc}
\hline location of lesions & n infections & $\%$ \\
\hline Head & 52 & 33.3 \\
Neck & 33 & 21.1 \\
Back & 49 & 31.4 \\
Abdomen & 10 & 6.4 \\
Front legs & 10 & 6.4 \\
Back legs & 2 & 1.2 \\
\hline Total & 156 & 100 \\
\hline
\end{tabular}

Table 4: Percentage of infection with S. scabiei according to Seasons of the year

\begin{tabular}{lccc}
\hline Seasons & n examined & n infected & $\%$ \\
\hline Winter & 119 & 71 & 59.6 \\
Spring & 104 & 35 & 33.6 \\
Summer & 106 & 17 & 16.0 \\
Autumn & 90 & 36 & 40.0 \\
\hline Total & 416 & 156 & 37.5 \\
\hline
\end{tabular}

The results of this study revealed the efficacy of the aqueous extract of $H$. articulate plant in killing $S$. scabiei parasites. Concentrations $5,7.5,10 \mathrm{mg} / \mathrm{ml}$ of the aqueous extract were used and compared with the Abamectin drug. In control group 1, the infection continued until the end of the experiment, where the average infection level was 3.27, $3.42,3.56,3.86$ mites/light field for days $0,7,14$, and 21 respectively. Group 2 was treated with $0.2 \mathrm{mg} / \mathrm{kg}$ of body weight of Abamectin drug the average infection level was 3.86 mite/light field before treatment and decreased to 1.25 mite/light field on day 7 of treatment and on day 14 the mite parasites completely disappeared. For group 3, which was treated with $5 \mathrm{mg} / \mathrm{ml}$ of aquatic extract from the $H$. articulate plant, the average level of infection before treatment was 3.55 mite/ light field and decreased to 1.51 and 0.44 mite/ light field on days 7 and 14, respectively, by the 21 st day after treatment, the parasites had completely disappeared, 
with an average infection level of 0 mite/ light field. Whereas group 4 was treated with a concentration of $7.5 \mathrm{mg} / \mathrm{mL}$ of aquatic extract, the average infection level decreased from $3.77 \mathrm{mites} /$ light field to 1.66 and 0.26 mite/light field on day 7,14 respectively of treatment, on day 21 , the scabies mites disappeared completely. Moreover, group 5 was treated with a concentration of $10 \mathrm{mg} / \mathrm{ml}$ of aquatic extract, which significantly affected the mite parasites and led to a decrease in average infection level from 3.84 mites/light field to 1.12 mites/light field on day 7 of treatment, and on day 14 all parasites were eliminated (Table 5).

Table 5: The effect of the aquatic extract of the Nitol plant compared with the drug abamectin on the average infection level of S. scabiei parasites

\begin{tabular}{lcccc}
\hline Group & \multicolumn{4}{c}{ Average infection level (mite / light field) \pm standard error } \\
\cline { 2 - 5 } & 0 day & 7 day & 14 day & 21 day \\
\hline Control (G1) & $3.27 \pm 0.44 \mathrm{a}$ & $3.42 \pm 0.34 \mathrm{a}$ & $3.56 \pm 0.66 \mathrm{a}$ & $3.86 \pm 0.38 \mathrm{a}$ \\
Abamectin $0.2 \mathrm{mg} / \mathrm{kg}$ & $3.86 \pm 0.52 \mathrm{a}$ & $1.25 \pm 0.22 \mathrm{~b}$ & $0 \mathrm{~d}$ & $0 \mathrm{~d}$ \\
Abamectin $5 \mathrm{mg} / \mathrm{kg}$ & $3.55 \pm 0.48 \mathrm{a}$ & $1.51 \pm 0.24 \mathrm{~b}$ & $0.44 \pm 0.32 \mathrm{c}$ & $0 \mathrm{~d}$ \\
Abamectin $7.5 \mathrm{mg} / \mathrm{kg}$ & $3.77 \pm 0.25 \mathrm{a}$ & $1.66 \pm 0.20 \mathrm{c}$ & $0.26 \pm 0.08 \mathrm{c}$ & $0 \mathrm{~d}$ \\
Abamectin $10 \mathrm{mg} / \mathrm{kg}$ & $3.84 \pm 0.77 \mathrm{a}$ & $1.12 \pm 0.06 \mathrm{c}$ & $0 \mathrm{~d}$ & $0 \mathrm{~d}$ \\
\hline
\end{tabular}

Different characters within the column indicate significant differences between the coefficients within the level of significance $\mathrm{P}<0.05$ according to the test LSD.

\section{Discussion}

The results showed a high infection of scabies mite in cows in Anbar province, and these results are higher than what was recorded by Mustafa (8) in Sulaymaniyah province, where he recorded an infection rate of $13.8 \%$. and the results of Shahatha (19) which recorded a rate of $34.6 \%$ in Anbar province. But it is less than what the researcher Zangana et al. (7) found, which amounted to $57.5 \%$ in Duhok province, these differences may be attributed to variations in the environment, climate, access to veterinary services, and other breeding practices such as concern for hygiene conditions in the fields of livestock breeding by livestock keepers.

The reason for the prevalence of scabies disease in Anbar province is due to the mismanagement of the herd by livestock keepers, failure to adhere to hygiene conditions in barns and animal husbandry fields, and direct contact with sources of infection such as dogs and cats plays a major role in the spread of infection, In addition, the spread of insects, especially mosquitoes and flies, has a major role in the spread of disease, as insects are among the mechanical factors that transmit infection between animals, also the failure to continue treatment by livestock keepers (20).

Shahatha (21) stated that poor animal health and body condition, malnutrition, harsh climatic conditions, and animal infestation with parasitic or other infectious diseases are predisposing factors for scabies. The difference may also be due to different diagnostic methods and Hamoo et al. (22) stated that precise diagnostic methods should be used to distinguish between types of parasites that cause diseases in humans and animals, including ectoparasites.

The results indicated a higher incidence of $S$. scabiei parasites in young cows compared to older ages, this is consistent with what Ahmed et al. (23), the reason for the higher prevalence of scabies in young animals compared to it for older animals is attributed to keeping young and adult animals together and thus infection through direct contact with each other with biting. In addition, farmers in most villages in Anbar province are not well-versed in wealth management practices modern animal. On the other hand, Head lesions were more present and more pronounced than other lesions on other parts of the body, and this corresponds to the study of Shahatha (9), the reason for this is that the parasite easily attaches to areas of low hair like the head and back.

The results confirmed that the seasons of the year had a significant effect on the rate of scabies mite infestation, as the highest infestation rate was recorded in the winter season and the lowest in the summer, this corresponds to results Abo-Elhassan (24).

The reason for the higher infection rates in the winter season compared to the summer season is the speed of transmission of the scabies parasite through direct contact and contact between animals in cold weather, in addition, ectoparasite activity increases with low temperature and high humidity, and overcrowding during the winter months are conducive to the rapid spread of mites' life cycle (9).

The therapeutic trial demonstrated the effective effect of the concentrations of the aqueous extract of the Nitol plant on the scabies parasites, this agrees with a Shahatha (9) and Aboelhadid et al. (11).

The effectiveness of the aquatic extract of $H$. articulate plant and its significant effect on S. scabiei parasite is due to its content of effective compounds, such as alkaloids, fuocumarins, glycosides flavones, tannins, saponins, and volatile oils which affect the production of enzymes and other vital components in the parasite, thus causing cell destruction and parasite death. Also, it prevents the passage of ions through the cell membrane and affects the biological 
activities of the parasite by disrupting the acetylcholine which controls all physiological functions of the parasite leading to parasite death (17). Shahatha (25) indicated that saponins have inhibitory efficacy through its effect on enzyme activity.

The therapeutic field trial showed a clear clinical improvement in all treated cows. The study also revealed that the therapeutic efficacy of the highest concentration of aqueous extract of $H$. articulate plant is equal to the effectiveness of the drug, as measured by analyzes of skin abrasion, body condition, and clinical outcome changes.

\section{Conclusion}

This study concluded that the cows of Anbar province were infected with scabies mites by a large percentage, this necessitates the establishment of an integrated control approach through treatment with effective plant extracts and to maintain the cleanliness of the animal environment. so, it is necessary to find safe treatment methods for this disease using medicinal herbs and plants because they contain many effective compounds that lead to the death of parasites. where the significant effect of the aqueous extract of the Nitol plant was observed on the scabies mites, and this is considered one of the good strategic alternatives for the use of chemical drugs that harm human health, animals, and the environment.

\section{Acknowledgments}

The author would like to thank the College of Science, University of Anbar, for providing facilities.

\section{Conflict of interest}

The authors declare that no conflict of interest exists.

\section{References}

1. Heath ACG. Climate change and its potential for altering the phenology and ecology of some common and widespread arthropod parasites in New Zealand. New Zeal Vet J. 2021;69(1):5-19. DOI: $\underline{10.1080 / 00480169.2020 .1787276}$

2. Cerda R, Avelino J, Harvey CA, Gary C, Tixier P, Allinne C. Coffee agroforestry systems capable of reducing disease-induced yield and economic losses while providing multiple ecosystem services. Crop Prot. 2020;134:10514. DOI: 10.1016/i.cropro.2020.105149

3. De AK, Sawhney S, Mondal S, Ponraj P, Ravi SK, Sarkar G, Bhattacharya D. Host-parasite interaction in Sarcoptes scabiei infestation in porcine model with a preliminary note on its genetic lineage from India. Anim. 2020;10(12):2312. DOI: 10.3390/ani10122312

4. Koche SK, Hunderra GC, Getahun AM. Study on prevalence and associated risk factors of mange mite infestations in cattle in Damot Woyde District, Wolaita Zone, Southern Ethiopia. J Vet Med Anim Heal. 2018;10(12):266-272. DOI: 10.5897/JVMAH2018.0729

5. Ambilo A, Kebede A. Prevalence of major skin diseases of cattle in and around Hawassa, Southern Ethiopia. Am J Bioch Sci Res. 2019;2:116122. DOI: $10.34297 / A J B S R .2019 .02 .000586$
6. Haggag YN, Nossair MA, Habib HM, Mohammad A M, Ayoub MA. Prevalence of mites in some clinically infected animals in Behera province. Egypt Vet Med Soc Par J. 2018;14(1);32-41. DOI: 10.21608/EVMSPJ.2018.33970

7. Zangana IK, Ali BA, Naqid IA. Distribution of ectoparasites infested sheep and goats in Duhok province, north Iraqi. Basrah J Vet Res. 2013;12(1):54-64. DOI: 10.33762/BVETR.2013.76188

8. Mustafa B. Detection on ectoparasites on small ruminants and their impact on the tanning industry in Sulaimani province. Iraqi $\mathbf{J}$ Vet Sci. 2019;33(2):303-309. DOI: 10.33899/ijvs.2019.162995

9. Shahatha SS. Epidemiological, diagnostic and therapeutic study for mange in sheep of Anbar province-Iraq. Iraqi J Vet Sci. 2020;34(1):17. DOI: $10.33899 /$ ijvs.2020.163587

10. Blakelock RA. Notes on the flora of Iraq with keys: Part IV. Kew Bull. 1957;461-497. DOI: $10.2307 / 4113726$

11. Aboelhadid SM, Mahrous LN, Hashem SA, Abdel-Kafy EM, Miller RJ. In vitro and in vivo effect of Citrus limon essential oil against sarcoptic mange in rabbits. Parasitol Res. 2016;115(8):3013-3020. DOI: 10.1007/s00436-016-5056-8

12. Li M, Liu B, Bernigaud C, Fischer K, Guillot J, Fang, F. Lemongrass (Cymbopogon citratus) oil: A promising miticidal and ovicidal agent against Sarcoptes scabiei. PLOS Org J Neg Trop Dis. 2020;14(4):8225. DOI: 10.1371 /journal.pntd.0008225

13. Hatem A, Abou Turab M, Abdul-Zahra HK, Muhammad M. A survey of chewing lice of some raptors in southern Iraq, with remarks on prevalence and occurrence. Iraqi J Vet Sci. 2021;35(2):287-290. DOI: 10.33899/ijvs.2020.126717.1365

14. Cloes EH. Veterinary clinical pathology. $4^{\text {th }}$ ed. Philadelphia: Sanders Company; 1986. 488 p. DOI: 10.1016/j.jclepro.2017.09.265

15. Smets K, Vercruysse J. Evaluation of different methods for the diagnosis of scabies in swine. Vet Parasitol. 2000;9(1-2):137-145. DOI: 10.1016/S0304-4017(00)00222-3

16. Kanojiya D, Shanker D, Sudan V, Jaiswal AK, Parashar R. In vitro and in vivo efficacy of extracts of leaves of Eucalyptus globulus on ovine gastrointestinal nematodes. Parasitol Res. 2015;114(1):141-148. DOI: 10.1007/s00436-014-4169-1

17. Shahatha SS. An Epidemiological and therapeutic study of the Cryptosporidium parvum parasite in some farm animals in Anbar province, Iraq. J Glo Pham Tech Parasite. 2019;10(11):147-152. [available at]

18. SAS. Statistical Analysis System, User's Guide. Statistical version 9.1 ed. Cary: SAS Institute; 2012. 5121 p. [available at]

19. Graham WC, Price M A. Dentition as a measure of physiological age in cows of different breed types. Cana J Ani Sci. 1982;62(3):745-750. DOI 10.4141/cjas82-091

20. Shahatha SS. Evaluation the efficiency of the fungus Metarhizium anisopliae as biocontrol agent for adults of hard ticks Hyalomma anatolicum. Iraqi J Vet Sci. 2019;33(2):57-62. DOI: 10.33899/ijvs.2019.163088

21. Shahatha SS. An Epidemiological and diagnostic study of Anaplasma ovis parasite in native goats in Anbar province-Iraq. Int J Drug Del Tech, 2019;9(01), 34-38. DOI: 10.25258/ijddt.9.1.6

22. Hamoo RN, Al-Rubaye FS, Mustafa NG. Genotyping study of Fasciola gigantica isolated from cattle in Aqrah city, Iraq. Iraqi $\mathrm{J}$ Vet Sci. 2020;34(1):123-127. DOI: 10.33899/ijvs.2019.125621.1108

23. Ahmed MA, Elmahallawy EK, Gareh A, Abdelbaset AE, El-Gohary FA, Elhawary NM, Abushahba, MF. Epidemiological and histopathological investigation of sarcoptic mange in camels in Egypt. Anim. 2020;10(9):14. DOI: 10.3390/ani10091485

24. Abo-Elhassan EM. Evaluation of the prevalence and oxidative status in sheep infected with Sarcoptic scabiei in Ismailia governorate. Egypt Egy Vet Med Soc Parasitol J. 2019;15(1):114-129. DOI: 10.21608/evmspi.2020.97609

25. Shahatha SS. An Epidemiological, diagnostic and therapeutic study of Giardia lamblia in Anbar Province, Iraq. Int $\mathbf{J}$ Drug Deli Tech. 2019:9(01):39-45. DOI: 10.25258/ijddt.9.2.30 


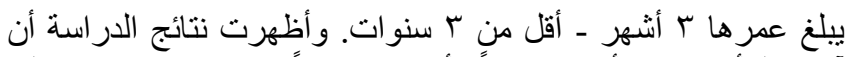

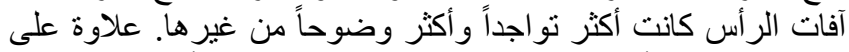

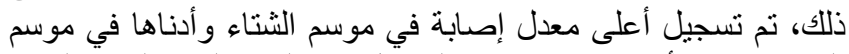

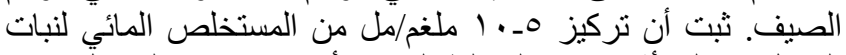

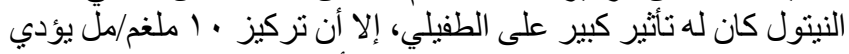

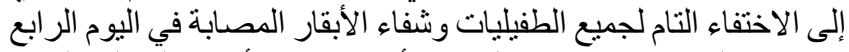

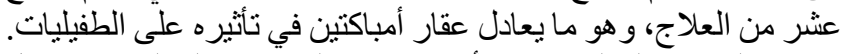

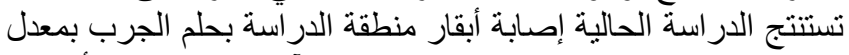

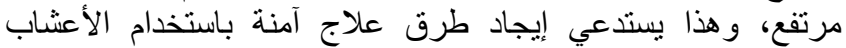

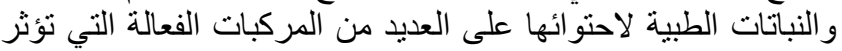

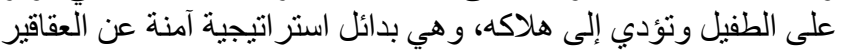

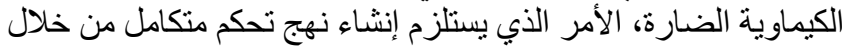
المعالجة بالمستخلصات النباتية الفعالة والمحافظة على نظافة بيئة الحيو انات.

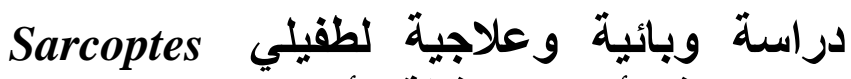
scabiei سعاد شلال شحاذة، إنعام محمد عايد و محمد عثمان موسى مركز در اسات الصحر اء، جامعة الأنبار، الأنبار ، العراق

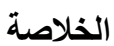

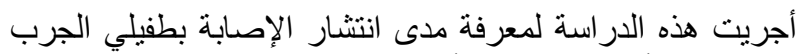

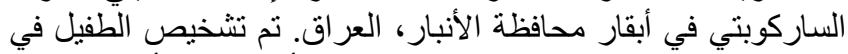

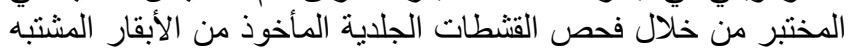

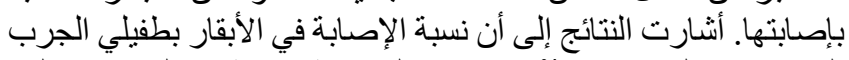

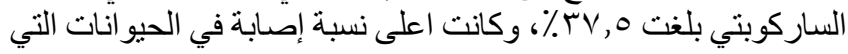

